\title{
PENGARUH PROSEDUR PEMBERIAN KREDIT PEMILIKAN RUMAH (KPR) SUBSIDI DAN GOOD CORPORATE GOVERNANCE TERHADAP KINERJA REALISASI KREDIT DENGAN FASILITAS SUBSIDI BANTUAN UANG MUKA SEBAGAI VARIABEL INTERVENING DI BANK BTN CABANG TANJUNGPINANG
}

\author{
Tommy Munaf \\ Program Studi Akuntansi, Sekolah Tinggi Ilmu Ekonomi Pembangunan Tanjungpinang \\ tommy.btn98@gmail.com
}

\begin{abstract}
This study aims to determine empirically the influence of the procedures for granting credit and good corporate governance on the performance of credit realization by subsidizing down payment assistance as an intervening variable. This study uses a sample of 107 employees at Bank BTN Tanjungpinang Branch. The data obtained were analyzed using "path analysis".

The results of this study are the lending procedure has a direct and significant effect on the performance of credit realization with a path coefficient value of 0.183 and significant at 0.036 sig probability $\leq a=0.05$, good corporate governance direct and significant influence on the credit realization performance with a path coefficient of 0.188 and significant at 0.033 sig probability $\leq a=0.05$, lending procedure direct and significant influence on the subsidy for advance assistance with a path coefficient value of 0.312 and significant at sig 0.000 probability $\leq a=0.05$, good corporate governance direct and significant influence on money aid subsidies face with path coefficient value of 0.333 and significant at sig probability $0.000 \leq a=0.05$, subsidy of advance cash assistance direct and significant influence on credit realization performance with path coefficient value of 0.641 and significant at sig probability $0.000 \leq a=0.05$, pr Credit provision procedures have a significant effect on the performance of credit realization through subsidy for advance assistance which is an intervening variable with a coefficient value of 0.199>0.183 direct coefficient value, good corporate governance has a significant effect on the performance of credit realization through subsidy for advance assistance which is an intervening variable with value coefficient 0.213>0.188 direct coefficient value.
\end{abstract}

Keywords: Credit delivery procedures, good corporate governance, Advance aid subsidies, Performance

\section{PENDAHULUAN}

Lembaga keuangan atau yang biasa disebut dengan bank saat ini mengalami pertumbuhan yang sangat pesat. Perbankan memiliki kegiatan utama yaitu menghimpun dana dari masyarakat dalam bentuk simpanan giro, tabungan, dan deposito untuk disalurkan kembali kepada masyarakat berbentuk penyaluran kredit.
Hampir seluruh kegiatan sekarang berhubungan dengan perbankan, mulai dari transaksi, pendanaan, sampai dengann pinjaman.

Kredit merupakan bentuk penyaluran atau memperoleh dana secara cepat. Kredit adalah semua pinjaman yang harus dibayar kembali bersama bunganya oleh peminjam 
sesuai dengan perjanjian yang telah disepakati, (Hasibuan, 2014:87). Salah satu jenis kredit yang sampai saat ini masih diminati dan dibutuhkan oleh masyarakat adalah KPR (Kredit Pemilikan Rumah). KPR Bersubsidi yang disubsidikan khususoleh pemerintah yang bekerjasama dengan Kementrian Pekerjaan Umum dan Perumahan Rakyat diperuntukkan bagi Masyarakat Berpenghasilan Rendah (MBR).

Sebuah bank dalam melakukan suatu proses kredit tetap mengacu kepada prinsip Good Corporate Governance (GCG). Kebutuhan untuk menerapkan prinsip-prinsip good corporate governance (GCG) dirasakan perlu untuk menjaga "kepercayaan". Banyak sekali permasalahan yang timbul saat prosedur kredit sulit mengidentifikasi karakter konsumen, proses good corporate governance yang terhambat, sulitnya mencari sasaran konsumen yang tepat dalam pemberian fasilitas subsidi uang muka dan menurunnya kinerja realisasi KPR di Bank BTN.

\section{Tujuan Penelitain}

Berdasarkan latar belakang yang telah diuraikan diatas, maka tujuan dalam penelitian ini adalah :

1. Untuk mengetahui apakah prosedur pemberian kredit KPR subsidi berpengaruh terhadap kinerja realisasi kredit di Bank BTN Cabang Tanjungpinang.

2. Untuk mengetahui apakah good corporate governance berpengaruh terhadap kinerja realisasi kredit di Bank BTN Cabang Tanjungpinang.

3. Untuk mengetahui apakah prosedur pemberian kredit KPR subsidi berpengaruh terhadap fasilitas bantuan subsidi uang muka di Bank BTN Cabang Tanjungpinang.

4. Untuk mengetahui apakah good corporate governance berpengaruh terhadap fasilitas bantuan subsidi uang muka di Bank BTN Cabang Tanjungpinang.

5. Untuk mengetahui apakah fasilitas bantuan subsidi uang muka berpengaruh terhadap kinerja realisasi kredit di Bank BTN Cabang Tanjungpinang.

6. Untuk mengetahui apakah prosedur pemberian kredit KPR subsidi berpengaruh terhadap kinerja realisasi kredit melalui fasilitas bantuan subsidi uang muka sebagai variabel intervening di Bank BTN Cabang Tanjungpinang.

7. Untuk mengetahui apakah good corporate governance berpengaruh terhadap kinerja realisasi kredit melalui fasilitas bantuan subsidi uang muka sebagai variabel intervening di Bank BTN Cabang Tanjungpinang.

\section{KAJIAN TEORI DAN METODE Kajian Teori \\ Kinerja Realisasi Kredit}

Rogers dalam Mahmudi (2015) menyatakan bahwa kinerja merupakan suatu konstruk yang bersifat multidimensional, pengukurannya juga bervariasi tergantung pada kompleksitas faktor-faktor yang membentuk kinerja. Faktor-faktor yang mempengaruhi kinerja adalah:

1. Faktor personal/individu

2. Faktor kepemimpinan

3. Faktor sistem

4. Faktor kontekstual/situasional

\section{Subsisi Bantuan Uang Muka}

Bantuan uang muka adalah bantuan pemerintah yang tidak memenuhi kriteria bantuan sosial yang diberikan kepada masyarakat berpenghasilan rendah dalam bentuk uang muka kredit/pembiayaan pemilikan rumah bersubsidi untuk rumah tapak. Menurut keputusan menteri pekerjaan umum dan perumahan rakyat nomor 552/KPTS/M/2016 tentang batasan penghasilan kelompok sasaran $\mathrm{kpr}$ bersubsidi adalah:

1. Batasan Penghasilan

2. Batasan Harga Jual

3. Syarat Hunian

\section{Prosedur Pemberian Kredit}

Prosedur adalah suatu urut-urutan pekerjaan kerani (clerical), biasanya melibatkan beberapa orang dalam satu bagian atau 
lebih, disusun untuk menjamin adanya perlakuan yang seragam terhadap transaksi transaksi perusahaan yang sering terjadi (Zaki Baridwan, 2009:3). Dalam bahasa latin, kredit berasal dari bahasa "credere" yang artinya percaya. Artinya pihak yang memberikan kredit percaya kepada pihak yang menerima kredit bahwa kredit yang diberikan pasti akan terbayar (Ismail, 2010:3). Terdapat lima indikator dalam penelitian ini yang diambil dari buku Kasmir (2014) yaitu:

\section{Character \\ 2. Capacity \\ 3. Capital \\ 4. Condition \\ 5. Colleteral}

\section{Good Corporate Governance}

GCG diperlukan untuk mendorong terciptanya pasar yang efisien, transparan dan konsisten dengan peraturan perundangundangan.Penerapan GCG perlu didukung oleh tiga pilar yang saling berhubungan, yaitu negara dan perangkatnya sebagai regulator, dunia usaha sebagai pelaku pasar, dan masyarakat sebagai pengguna produk dan jasa dunia usaha (Wahyudin, 2014:36).

Dalam melaksanakan kegiatan usahanya bank harus menganut prinsip-prinsip, sebagai berikut :

1. Keterbukaan (Transparency)

2. Akuntabilitas (Accountability)

3. Tanggung Jawab (Responsibility)

4. Independensi (Independency)

5. Kewajaran (Fairness)

\section{Metode}

Pendekatan penelitian yang digunakan dalam penelitian ini adalah pendekatan kuantitatif, sementara jenis penelitiannya adalah survey. Data dikumpulkan melalui pengisian kuesioner dengan alat analisis menggunakan path analysis.

Melalui penelitian ini diharapkan dapat mengetahui seberapa besar pengaruh prosedur pemberian kredit pemilikan rumah (KPR) subsidi dan good corporate governance terhadap kinerja realisasi kredit dengan fasilitas subsidi bantuan uang muka sebagai variabel intervening

\section{Populasi, Sampel, Besar Sampel dan Penarikan Sampel}

Populasi adalah wilayah generalisasi yang terjadi dari objek atau subjek yang menjadi kuantitas dan karateristik tertentu yang ditetapkan oleh peneliti untuk dipelajari dan kemudian ditarik kesimpulannya (Rumengan, 2015:140). Populasi dalan penelitian ini adalah keseluruhan karyawan di Bank BTN cabang Tanjungpinang sebanyak 147 orang

Sampel adalah sebagian dari jumlah dan karateristik yang dimiliki oleh populasi tertentu. Sampel yang diambil dari populasi harus betul-betul representative/ mewakili (Sugiyono. 2014: 149). Dalam penelitian ini jumlah sampel yang ditetapkan sebanyak 107 orang yang diperoleh dengan menggunakan rumus Slovin.

\section{Prosedur Pengumpulan Data}

Data dalam penelitian ini adalah data primer yang dikumpulkan dengan menggunakan kuesioner. Bersama kuesioner dilampirkan surat yang menjelaskan maksud dan tujuan pengisian kuesioner serta waktu pengembalian kuesioner yang telah diisioleh responden.

Teknik penyerahan kuesioner peneliti secara langsung untuk menyebarkan kuesioner dan mengambilnya langsung. Teknik ini lebih baik dibandingkan dengan melalui perantara karena dapat memperkecil perbedaan interprestasi antara responden dengan peneliti. 


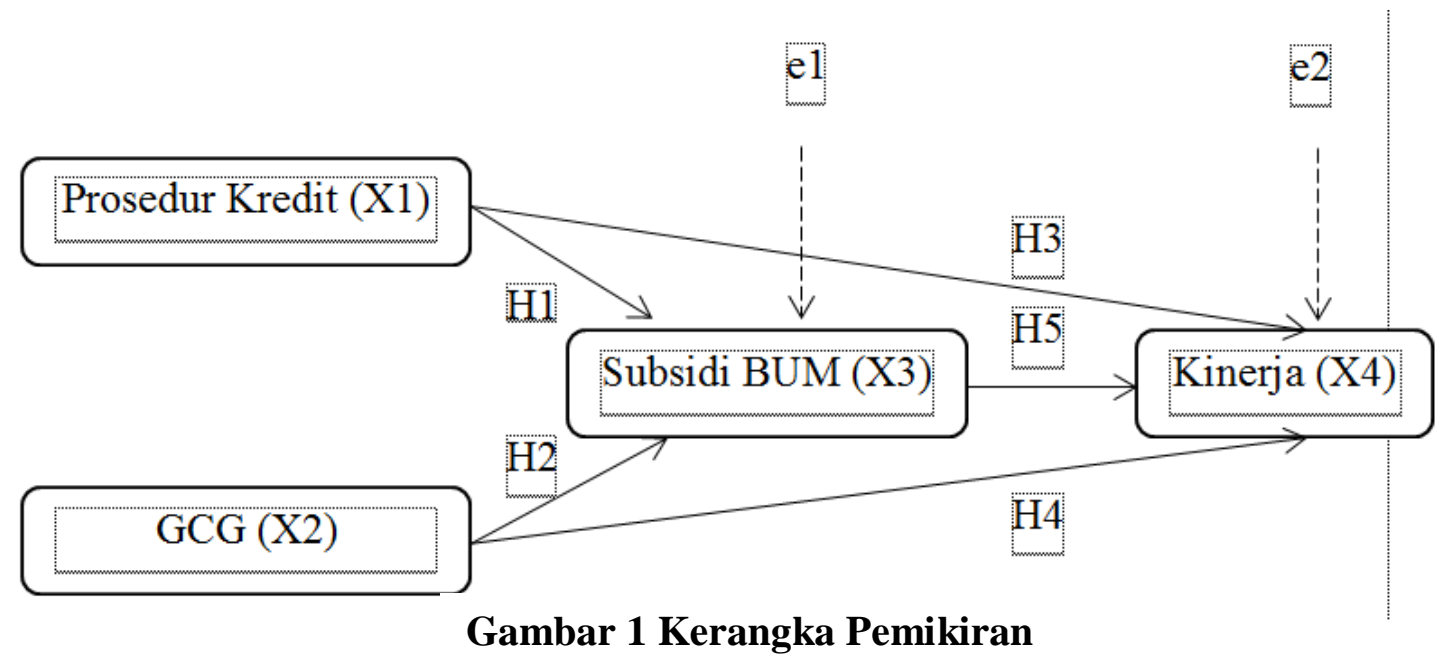

HASIL DAN PEMBAHASAN

Gambaran Umum Bank BTN

Bank BTN telah hadir di Indonesia sejak tahun 1897 dengan nama Postpaarbank pada masa pemerintahan belanda, perubahan nama pada tahun 1950 menjadi Bank Tabungan Pos oleh Pemerintahan Republik Indonesia, dan pada tahun 1963 berganti nama menjadi Bank Tabungan Negara. Bank BTN telah hadir di Indonesia selama 68 tahun dan menjadi salah satu Bank penyalur KPR Subsidi. Dalam menerapkan bisnis Bank BTN sebagai salah satu Bank penyalur KPR Subsidi maka Bank BTN telah menerapka peraturan pemerintahnomor 42/PRT/M/2015 tentang Bantuan uang muka bagi masyarakat berpenghasilan rendah untuk meningkatkan aksesibilitas kredit/pembiayaan pemilikan rumah bersubsidi.

\section{Deskripsi Sampel Penelitian}

Responden terdiri dari 107 responden, terbagi menjadi responden berjenis kelamin laki-laki sebanyak 81 orang $(75,7 \%)$, sedangkan responden perempua berjumlah 26 orang $(24,3 \%)$. Responden

\section{Teknik Analisis Data}

Analisis data dilakukan dengan menggunakan Path Analysis dengan bantuan program SPSS versi 23. Model penelitian sebagaimana Gambar 1. berpendidikan SMA sebanyak 3 orang $(2,8 \%)$, Diploma sebanyak 27 orang $(25,2 \%)$, Strata 1 sebanyak 76 orang $(71 \%)$ dan Strata 2 sebanyak 1 orang $(0,9 \%)$.

\section{Hasil Pengujian Hipotesis}

Pengujian hipotesis ini didasarkan atas pengolahan data penelitian dengan menggunakan analisis SPSS.

\section{Uji Validitas}

Dari tabel 1 dapat diketahui bahwa butir pertanyaan pada variabel dependen adalah valid, karena nilai r-hitung > 0,300. Dan seluruh probabilitas yang dihitung < probabilitas yang ditetapkan sebesar 0,05. Oleh karena itu, seluruh item pertanyaan dapat dilanjutkan pada pengujian relalibilitas. 
Tabel 1. Hasil Uji Validitas

\begin{tabular}{|c|c|c|c|c|}
\hline Variabel & Butir Pertanyaan & Nilai Korelasi & Batas & Keterangan \\
\hline \multirow{10}{*}{$\begin{array}{c}\text { Kinerja Realisasi } \\
\text { Kredit }\left(\mathrm{X}_{4}\right)\end{array}$} & 1 & 0,558 & 0,300 & Valid \\
\hline & 2 & 0,651 & 0,300 & Valid \\
\hline & 3 & 0,516 & 0,300 & Valid \\
\hline & 4 & 0,555 & 0,300 & Valid \\
\hline & 5 & 0,558 & 0,300 & Valid \\
\hline & 6 & 0,652 & 0,300 & Valid \\
\hline & 7 & 0,587 & 0,300 & Valid \\
\hline & 8 & 0,649 & 0,300 & Valid \\
\hline & 9 & 0,518 & 0,300 & Valid \\
\hline & 10 & 0,549 & 0,300 & Valid \\
\hline \multirow{10}{*}{$\begin{array}{l}\text { Subsidi Bantuan } \\
\text { Uang Muka }\left(\mathrm{X}_{3}\right)\end{array}$} & 1 & 0,598 & 0,300 & Valid \\
\hline & 2 & 0,578 & 0,300 & Valid \\
\hline & 3 & 0,54 & 0,300 & Valid \\
\hline & 4 & 0,631 & 0,300 & Valid \\
\hline & 5 & 0,647 & 0,300 & Valid \\
\hline & 6 & 0,587 & 0,300 & Valid \\
\hline & 7 & 0,564 & 0,300 & Valid \\
\hline & 8 & 0,595 & 0,300 & Valid \\
\hline & 9 & 0,53 & 0,300 & Valid \\
\hline & 10 & 0,813 & 0,300 & Valid \\
\hline \multirow{10}{*}{$\begin{array}{c}\text { Prosedur } \\
\text { Pemberian } \\
\text { Kredit }\left(X_{1}\right)\end{array}$} & 1 & 0,581 & 0,300 & Valid \\
\hline & 2 & 0,523 & 0,300 & Valid \\
\hline & 3 & 0,559 & 0,300 & Valid \\
\hline & 4 & 0,657 & 0,300 & Valid \\
\hline & 5 & 0,627 & 0,300 & Valid \\
\hline & 6 & 0,643 & 0,300 & Valid \\
\hline & 7 & 0,687 & 0,300 & Valid \\
\hline & 8 & 0,655 & 0,300 & Valid \\
\hline & 9 & 0,599 & 0,300 & Valid \\
\hline & 10 & 0,66 & 0,300 & Valid \\
\hline \multirow{10}{*}{$\begin{array}{l}\text { Good Corporate } \\
\text { Governance }\left(\mathrm{X}_{2}\right)\end{array}$} & 1 & 0,553 & 0,300 & Valid \\
\hline & 2 & 0,555 & 0,300 & Valid \\
\hline & 3 & 0,568 & 0,300 & Valid \\
\hline & 4 & 0,736 & 0,300 & Valid \\
\hline & 5 & 0,561 & 0,300 & Valid \\
\hline & 6 & 0,661 & 0,300 & Valid \\
\hline & 7 & 0,645 & 0,300 & Valid \\
\hline & 8 & 0,733 & 0,300 & Valid \\
\hline & 9 & 0,555 & 0,300 & Valid \\
\hline & 10 & 0,555 & 0,300 & Valid \\
\hline
\end{tabular}




\section{Uji Reliabilitas}

Tabel 2. Hasil Uji Reliabilitas

\begin{tabular}{lcccc}
\multicolumn{1}{c}{ Variabel } & Pertanyaan & Cronbach's Alpha & Batas & Keterangan \\
\hline $\begin{array}{l}\text { Kinerja Realisasi Kredit } \\
\left(\mathrm{X}_{4}\right)\end{array}$ & 10 & 0,780 & 0,600 & Realibel \\
\hline $\begin{array}{l}\text { Subsidi Bantuan Uang } \\
\text { Muka }\left(\mathrm{X}_{3}\right)\end{array}$ & 10 & 0,811 & 0,600 & Realibel \\
\hline $\begin{array}{l}\text { Prosedur Pemberian } \\
\text { Kredit }\left(\mathrm{X}_{1}\right)\end{array}$ & 10 & 0,821 & 0,600 & Realibel \\
\hline $\begin{array}{l}\text { Good Corporate } \\
\text { Governance }\left(\mathrm{X}_{2}\right)\end{array}$ & 10 & 0,815 & 0,600 & Realibel \\
\hline
\end{tabular}

Berdasarkan tabel 2 dapat diketahui bahwa semua variabel independen dan variabel dependen memiliki nilai lebih besar dari 0,600
Dengan ini masing-masing variabel tersebut didapatkan nilai Cronbach Alpha lebih besar dari 0,600 maka instrument penelitian ini dapat dikatakan reliabel

\section{Uji Normalitas}

\section{Tabel 3. Hasil Uji Normalitas}

\begin{tabular}{lccc}
\hline \multicolumn{1}{c}{ Variabel } & $\begin{array}{c}\text { Nilai Asymp. } \\
\text { Sig (2 Tailed }) \\
\text { atau nilai } \mathrm{P}\end{array}$ & $\begin{array}{c}\text { Kriteria Jika Nilai } \\
\mathrm{P}>0,05, \text { terima } \\
\text { Ho }\end{array}$ & Kesimpulan \\
\hline Kinerja Realisasi Kredit $\left(\mathrm{X}_{4}\right)$ & 0.961 & $\mathrm{P}>0,05$ & Normal \\
\hline $\begin{array}{l}\text { Subsidi Bantuan Uang Muka } \\
\left(\mathrm{X}_{3}\right)\end{array}$ & 0.168 & $\mathrm{P}>0,05$ & Normal \\
\hline Prosedur Pemberian Kredit $\left(\mathrm{X}_{1}\right)$ & 0.120 & $\mathrm{P}>0,05$ & Normal \\
\hline $\begin{array}{l}\text { Good Corporate Governance } \\
\left(\mathrm{X}_{2}\right)\end{array}$ & 0.195 & $\mathrm{P}>0,05$ & Normal \\
\hline
\end{tabular}

Pengujian normalitas menggunakan uji Kolmogrov-Smirnnov diatas, dapat dilihat bahwa nilai Asymp. Sig. (2-tailed) atau nilai $\mathrm{P}$ pada semua variabel penelitian ternyata memiliki nilai berada diatas 0,05 .
Dengan demikian dapat disimpulkan bahwa data sampel yang digunakan dalam penelitian ini berdistribusi normal. Artinya data yang digunakan penelitian ini dapat digunakan untuk pengujian hipotesis selanjutnya.

\section{Uji Linearitas}

Tabel 4. Hasil Uji Linearitas Struktur 1

\begin{tabular}{|c|c|c|c|c|c|}
\hline \multicolumn{6}{|c|}{ ANOVA $^{a}$} \\
\hline Model & Sum of Squares & df & Mean Square & $\mathrm{F}$ & Sig. \\
\hline Regression & 337,357 & 2 & 168,679 & 14,749 &, $000^{\mathrm{b}}$ \\
\hline Residual & 1189,385 & 104 & 11,436 & & \\
\hline Total & 1526,742 & 106 & & & \\
\hline
\end{tabular}


Tabel 5. Hasil Uji Linearitas Struktur 2

\begin{tabular}{lcrrrr}
\hline \multicolumn{7}{c}{ ANOVA $^{\mathbf{a}}$} & & & \\
\hline Model & Sum of Squares & df & Mean Square & F & Sig. \\
\hline Regression & 479,89 & 3 & 159,963 & 16,245 &, $000^{\mathbf{b}}$ \\
\hline Residual & 1014,21 & 103 & 9,847 & & \\
\hline Total & 1494,1 & 106 & & & \\
\hline a. Dependent Variable: Kinerja Realisasi Kredit & & & \\
\hline
\end{tabular}

Berdasarkan tabel 4, dapat diketahui bahwa nilai signifikan struktur 1sebesar $0.000<$ 0.05 dan nilai $F_{\text {hitung }}$ sebesar 14,749 maka dapat disimpulkan bahwa model regresi persamaan struktur pertama dengan persamaannya $X_{3}=p_{31} X_{1}+p_{32} X_{2}+e_{1}$ adalah linear.
Sedangkan tabel 5 memiliki nilai signifikan sebesar $0.000<0.05$ dan nilai $F$ hitung sebesar 16,245, maka dapat disimpulkan model regresi persamaan struktur kedua dengan persamaannya $\quad \mathrm{X} 4=\mathrm{p} 41 \mathrm{X} 1+$ $\mathrm{p} 42 \mathrm{X} 2+\mathrm{p} 43 \mathrm{X} 3$ + e1adalah linear.

\section{Uji Hipotesis}

Tabel 6. Perhitungan Pengaruh Langsung dan Tidak Langsung

\begin{tabular}{|c|c|c|c|}
\hline \multirow[b]{2}{*}{ Pengaruh Variabel } & \multicolumn{3}{|c|}{ Pengaruh Kausal } \\
\hline & Langsung & $\begin{array}{c}\text { Melalui } \\
\text { Subsidi Uang Muka }\end{array}$ & $\begin{array}{l}\text { Total dan } \\
\text { Sig }\end{array}$ \\
\hline $\begin{array}{l}\text { Prosedur Pemberian } \quad \text { Kredit } \\
\text { terhadap Kinerja Realisasi Kredit }\end{array}$ & 0,183 & - & $\begin{array}{c}0,183 \\
(0.036)^{*}\end{array}$ \\
\hline $\begin{array}{l}\text { Good Corporate Governance } \\
\text { terhadap Kinerja Realisasi Kredit }\end{array}$ & 0,188 & - & $\begin{array}{c}0,188 \\
(0.033)^{*}\end{array}$ \\
\hline 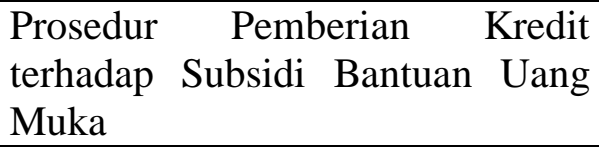 & 0,312 & - & $\begin{array}{c}0,312 \\
(0.000)^{*}\end{array}$ \\
\hline $\begin{array}{l}\text { Good Corporate Governance } \\
\text { terhadap Subsidi Bantuan Uang } \\
\text { Muka }\end{array}$ & 0,333 & - & $\begin{array}{c}0,333 \\
(0.000)^{*}\end{array}$ \\
\hline $\begin{array}{l}\text { Subsidi Bantuan Uang Muka } \\
\text { Terhadap Kinerja Realisasi Kredit }\end{array}$ & 0,641 & - & $\begin{array}{c}0,641 \\
(0.000)^{*}\end{array}$ \\
\hline $\begin{array}{l}\text { Prosedur Pemberian } \quad \text { Kredit } \\
\text { terhadap Kinerja Realisasi Kredit }\end{array}$ & - & $(0,312)(0,641)=0,199$ & 0,199 \\
\hline $\begin{array}{l}\text { Good Corporate Governance } \\
\text { terhadap Kinerja Realisasi Kredit }\end{array}$ & - & $(0,333)(0,641)=0,213$ & 0,213 \\
\hline
\end{tabular}


Berdasarkan Tabel 6 diketahui bahwa hasil perhitungan analisis jalur dan signfikansi pengaruh langsung antar variabel dapat dijelaskan sebagai berikut:

1. Hasil analisis jalur Prosedur Pemberian Kredit $\left(\mathrm{X}_{1}\right)$ terhadap Kinerja Realisasi Kredit $\left(\mathrm{X}_{4}\right)$ diperoleh koefisien jalur sebesar 0.183 dengan Sig. sebesar $0.036<0.05$. Oleh, maka dapat disimpulkan bahwa koefisien jalur adalah signifikan.

2. Hasil analisis jalur Good Corporate Governance $\left(\mathrm{X}_{2}\right)$ terhadap Kinerja Realisasi Kredit $\left(\mathrm{X}_{4}\right)$ diperoleh koefisien jalur sebesar 0.188 dengan Sig. sebesar $0.033<0.05$. Oleh, maka dapat disimpulkan bahwa koefisien jalur adalah signifikan.

3. Berdasarkan hasil analisis jalur Subsidi Bantuan Uang Muka $\left(\mathrm{X}_{3}\right)$ terhadap Kinerja Realisasi Kredit $\left(\mathrm{X}_{4}\right)$ diperoleh koefisien jalur sebesar 0.641 dengan Sig. sebesar $0.000<0.05$. Oleh, maka dapat disimpulkan bahwa koefisien jalur adalah signifik
4. Pengaruh Prosedur Pemberian Kredit $\left(\mathrm{X}_{1}\right)$ terhadap Kinerja Realisasi Kredit $\left(\mathrm{X}_{4}\right)$ melalui Subsidi Bantuan Uang Muka $\left(\mathrm{X}_{3}\right)$, diperoleh dari hasil perkalian antara koefisien regresi $\mathrm{X}_{1}$ dengan koefisien regresi $X_{3}$. Diperoleh nilai $0.199>0.183$ artinya Nilai Koefisien Tidak Langsung > Langsung, maka X1 mempunyai efek Signifikan terhadap X4 melalui X3 atau dengan Kata lain X3 merupakan variabel Intervening.

5. Pengaruh Corporate Governance $\left(X_{2}\right)$ terhadap Kinerja Realisasi Kredit $\left(\mathrm{X}_{4}\right)$ melalui melalui Subsidi Bantuan Uang Muka $\left(\mathrm{X}_{3}\right)$, diperoleh dari hasil perkalian antara koefisien regresi $X_{2}$ dengan koefisien regresi $X_{3}$. Diperoleh nilai $0.213>0.188$ artinya Nilai Koefisien Tidak Langsung > Langsung, maka X2 mempunyai efek Signifikan terhadap X4 melalui X3 atau dengan Kata lain X3 merupakan variabel Intervening.

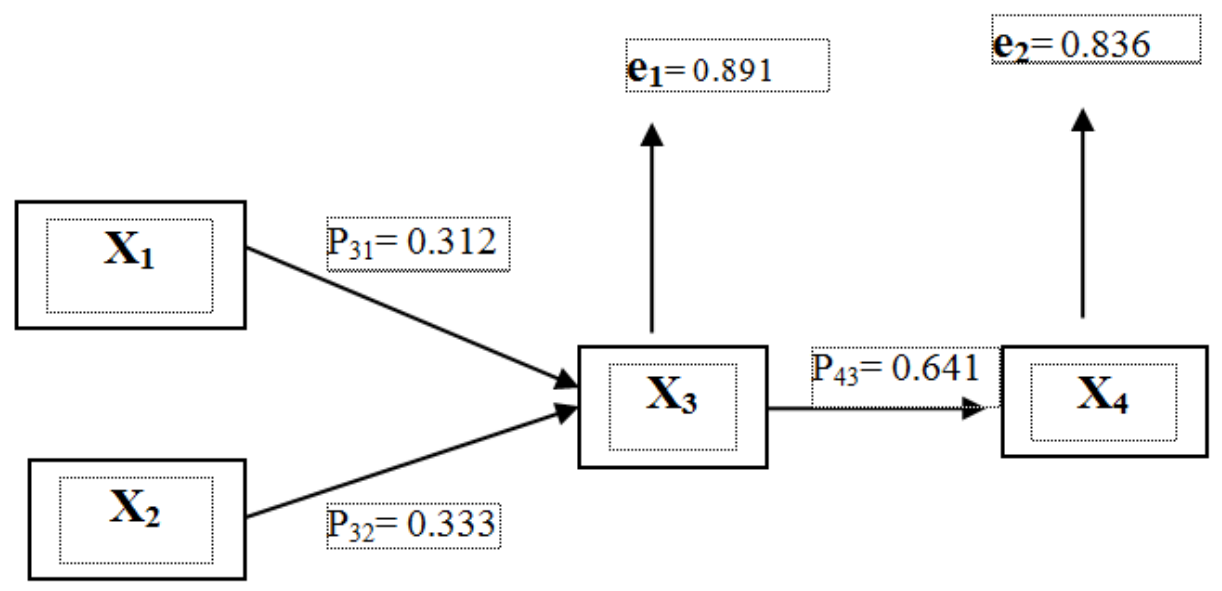

Gambar 2 Model Analisis Jalur

\section{KESIMPULAN}

1. Hasil pengujian menunjukkan terdapat pengaruh langsung yang secara signifikan prosedur pemberian kredit terhadap kinerja realisasi kredit dengan signifikan sebesar $0,036<0,05$.

2. Hasil pengujian menunjukkan terdapat pengaruh langsung yang secara signifikan Good Corporate Governance terhadap kinerja realisasi kredit dengan signifikan sebesar $0,033<0,05$.

3. Hasil pengujian menunjukkan terdapat pengaruh langsung yang secara signifikan Subsidi Bantuan Uang Muka terhadap kinerja realisasi kredit dengan signifikan sebesar $0,000<0,05$. 
4. Hasil pengujian menunjukkan terdapat pengaruh langsung yang secara signifikan prosedur pemberian kredit terhadap subsidi bantuan uang muka dengan signifikan sebesar $0,000<0,05$.

5. Hasil pengujian menunjukkan terdapat pengaruh langsung yang secara signifikan Good Corporate Governance terhadap subsidi bantuan uang muka dengan signifikan sebesar $0,000<0,05$.

6. Hasil pengujian menunjukkan terdapat pengaruh langsung yang secara signifikan prosedur pemberian kredit terhadap kinerja realisasi kredit melalui subsidi bantuan uang muka dengan koefisien jalur dengan koefisen jalur tidak langsung sebesar 0.199 lebih besar dari koefisien jalur langsung sebesar 0.183 .

7. Hasil pengujian menunjukkan terdapat pengaruh langsung yang secara signifikan good corporate governance terhadap kinerja realisasi kredit melalui subsidi bantuan uang muka dengan koefisien jalur dengan koefisen jalur tidak langsung sebesar 0.213 lebih besar dari koefisien jalur langsung sebesar 0.188 .

\section{REKOMENDASI}

1. Kepada karyawan Bank BTN Cabang Tanjungpinang khususnya unit kredit yang mengikatkan diri kepada perusahaan hendaknya mempertahankan dan meningkatkan semangat kerja untuk dapat terus melakukan proses kredit pemilikan rumah subsidi agar semakin banyak masyarakat berpenghasilan rendah dapat memiliki rumah.

2. Kepada Bank BTN Cabang Tanjungpinang untuk tetap konsisten menjalankan proses kredit pemilikan rumah subsidi guna mendukung program pemerintah dengan subsidi bantuan uang muka, namun tetap mengedepankan prinsip prinsip prudential banking.

3. Bagi peneliti lanjutan diharapkan dapat menambah beberapa variabel lain, baik variabel bebas maupun variabel terikat, guna perbaikan dan pengembangan dari hasil penelitian ini. Sehingga temuan yang diharapkan akan sangat membantu bagi perkembangan

\section{REFERENSI}

Rumengan, Jemmy, 2015, Metodologi Penelitian, Ciptapustaka Media, Bandung

Sudjarwo,2009, Manajemen Penelitian Sosial, Mandar Maju, Bandung

Juhaya, 2013, Dasar-dasar Perbankan, Pustaka Setia, Bandung

Zarkasyi, Wahyudin, 2008, Good Corporate Governance, Alfabeta, Bandung

Ikatan Bankir Indonesia, 2015, Mengelola Kredit Secara Sehat, Gramedia Pustaka Utama, Jakarta Pusat.

Afrizal, Mortigor, 2015. Pengaruh Informasi Akuntansi dan Informasi Non Akuntansi Terhadap Keputusan Kredit dengan pengaaman Sebagai Variabel Moderating Pada Bank Swasta Kota Batam. Tesis S2 Program Studi Magister Akuntansi Universitas Batam.

Ismail, 2010, Akuntansi Bank Teori dan Aplikasi Dalam Rupiah, Kencana, Jakarta

Kasmir, 2008, Dasar dasar Perbankan, Raja Grafindo Persada, Jakarta.

Martono, 2007, Bank dan Lembaga Keuangan Lainnya, Ekonisia, Yogyakarta

Ismail, 2011, Manajemen Perbankan, Kencana, Jakarta

Peraturan Menteri Pekerjaan Umum dan

Perumahanan Rakyat Republik Indonesia No.42/PRT/M/2015, Bantuan Uang Muka Bagi Masyarakat Berpenghasilan Rendah Untuk Meningkatkan Aksesibilitas Kredit / Pembiayaan Pemilikan Rumah Bersubsidi.

Abdillah, W (2017). Metode Penelitian Terpadu Sistem Informasi. Yogyakarta: Penerbit Andi

Ghozali, I (2011). Aplikasi Analisis Multivariate Dengan Program SPSS. Semarang: Badan Penerbit Universitas Diponegoro 
Kotler, P dan Keller, K.L (2012). Manajemen Pemasaran Edisi 14. Jakarta: PT. Indeks.

Rumengan, J (2015). Metode Penelitian Kuantitatif dan Kualitatif. Bandung: Ciptapustaka Media

Supranto, J. (2011). Pengukuran Tingkat Kepuasan Pelanggan untuk Menaikkan Pangsa Pasar. Jakarta: PT. Rineka Cipta.

Wibowo, A (2012). Aplikasi Praktis SPSS Dalam Penelitian. Yogyakarta: Gava Media

Widjana, M.A (2010). Determinan Faktor Penerimaan terhadap Internet Banking pada Nasabah Bank di Surabaya. Tesis. Surabaya: Sekolah Tinggi Ilmu Ekonomi Perbanas

www.btn.co.id www.btnproperty.com www.eloan.btn.co.id www.pupr.go.id 